\title{
Microbial Degradation Pathways of Acrylic Paint Thinner Gas in Biotrickling Filter and Comparison of Kinetic Models Under Different Gas Concentrations
}

\author{
QINWEI JIA ${ }^{1}$, JUN ZHOU ${ }^{1 *}$, HAONAN ZHANG ${ }^{1}$, TONG ZUO ${ }^{1}$, LUYU WANG ${ }^{1}$, \\ LEI GONG ${ }^{1 *}$, FENG GENG ${ }^{1}$
}

College of Environmental and Safety Engineering, Qingdao University of Science and Technology, 53 Zhengzhou Road, Qingdao, Shandong Province 266042, P. R. China

\begin{abstract}
In this study, the effect of inlet concentration of pollutants, empty bed residence time (EBRT) and liquid recycling velocity on the performance of the BTF was explored. The results showed the best operating characteristics of the biotrickling filter for this study were at an inlet concentration of 500 $\mathrm{mg} / \mathrm{m}^{3}$, the EBRT of $300 \mathrm{~s}$ and liquid recycling velocity of $25.46 \mathrm{~m} \mathrm{~h}^{-1}$. At this condition, the total removal efficiency of pollutants can reach more than $90 \%$. Among them, the removal efficiency of toluene and ethylbenzene was above 95\%, and the xylene (m-xylene, o-xylene) could reach more than $70 \%$, corresponding to elimination capacities (ECs) of $3.02 \pm 0.33 \mathrm{~g} \mathrm{~m}^{-3} \mathrm{~h}^{-1}, 1.81 \pm 0.2 \mathrm{~g} \mathrm{~m}^{-3} \mathrm{~h}^{-1}, 0.60$ $\pm 0.07 \mathrm{~g} \mathrm{~m}^{-3} \mathrm{~h}^{-1}$. Through the fatty acid identification system and $16 \mathrm{~S} \mathrm{rDNA}$ identification, it could be found that the four dominant bacteria (Bacillus cereus, Bacillus subtilis, Acinetobacter calcoaceticus, Belem Bacillus) had a significant effect on the removal of acrylic paint thinner. According to the detection of organic compounds by gas chromatography and the corresponding enzymes produced by four dominant bacteria, the pathways for microorganisms to degrade pollutants could be inferred. The absorption-biofilm theory and the adsorption-biofilm theory were used to simulate and verify the degradation process of exhaust gas at different concentrations respectively.
\end{abstract}

Keywords: biotrickling filter, acrylic paint thinner, microbial degradation pathway

\section{Introduction}

Acrylic paint is widely used as paint in automobile manufacturing, doors and windows, furniture, and other industries. In the spraying process, organic solvents are needed to dilute the acrylic paint. The widespread application of these organic solvents within the manufacturing industry unavoidably generates volatile organic compounds (VOC) into the atmosphere [1]. Environmental and health concerns due to VOC emissions have received significant attention from Chinese regulatory authorities in recent years due to the causing problems of increasing global warming, photochemical ozone smog, stratosphere ozone depletion, and the possibility to cause carcinogenic and mutagenic effects on human health [2-4]. Acrylic paint thinner is a common organic solvent, and it is mainly composed of a mixture of esters, alcohols, benzene series, and so on [5].

At present, the treatment technologies of VOC include [6] adsorption, high-temperature combustion, low-temperature condensation, semipermeable membrane separation and biotechnology. However, the price of sorbent was used in the adsorption method is high and the equipment is complex. In addition, the desorbed solution is difficult to handle and may cause secondary pollution. Adsorption is more suitable for high concentration, single component VOC treatment [7]. The high-temperature combustion method is also prone to secondary pollution, and high operating costs. Meanwhile, there are some potential safety problems [8]. Low-temperature condensation method has a high removal efficiency and free of impurities for the treatment of single organic exhaust gas, and usually combines with adsorption or combustion method [9]. The production of a semipermeable membrane separation is more expensive. During the process of preservation or use, it is very vulnerable to being contaminated and its performance

*email: zhoujun02296@163.com,gongleiqust@163.com 
needs to be improved [10]. Among these methods, biotechnology is frequently used due to its advantages, such as no secondary pollutants and low operational and investment costs [11-13].

Regarding biotechnology, compared with the traditional biological filter (BF), the biological trickling filter (BTF) has a water flow filled with inert fillers, which has a higher removal rate, lower energy consumption, and smaller footprint requirements [14]. It is necessary to study the performance of the BTF for engineering applications. The performance of BTF can be influenced by various factors, such as the structural type of BTF, the humidity of the trickling bed, ambient temperature, species of microorganisms, packing materials, inlet concentration, empty bed residence time (EBRT) and liquid recycling velocity [15]. Mohammed et al. [16] studied the influence of three operating parameters of inlet concentration, EBRT and liquid recycling velocity on the ethanethiol removal efficiency. It can be concluded from his research, with the inlet concentration increased, the removal efficiency decreased. In addition, with the increase of the EBRT, the removal efficiency increased steadily. When the EBRT was increased from the $30 \mathrm{~s}$ to $60 \mathrm{~s}$, the removal efficiency increased significantly. However, when the EBRT increased from the $60 \mathrm{~s}$ to $120 \mathrm{~s}$, the increase of the removal efficiency slowed down, and even no obvious increase was observed. And, the removal efficiency increases with the increase in liquid recycling velocity at the highest concentration $\left(1500 \mathrm{mg} / \mathrm{m}^{3}\right)$, but the increase in liquid recycling velocity has no significant effect on the removal efficiency at lower concentrations $\left(150\right.$ and $\left.300 \mathrm{mg} / \mathrm{m}^{3}\right)$. By studying the changes in inlet concentration, the EBRT and liquid recycling velocity, it is necessary to determine their parameters when the BTF reaches its optimal performance [17-18].

Most of kinetic models were developed to research the BTF. The gas-liquid biofilm model first was proposed by Ottengraf [19]. The model divides the purification process into three states: first-order reaction, zero-order reaction limited by diffusion rate, and zero-order reaction limited by microbial degradation ability. The model could be used to reflect the general process of biological methods for purifying pollutant substrates. Lebrero [20] obtained the total mass transfer coefficient of toluene in the BTF by establishing a model and experimental fitting. The first adsorption-biofilm theoretical model was proposed by Sun Juishi [21]. This model improved the shortcomings of Ottengraf's biofilm theory. It took into account the insoluble or poorly soluble pollutants, and more fully describes the process of purifying VOC by biological methods.

In this study, the performance of the BTF in treating acrylic paint thinner was studied by changing the inlet concentration of pollutants, the EBRT, and liquid recycling velocity. On this basis, the degradation mechanism of acrylic paint thinner was inferred by identifying microorganisms and detecting intermediate products. In addition, kinetic models were used to simulate the degradation process.

\section{Materials and methods}

\subsection{Materials}

\subsubsection{Nutrient medium}

The compositions of the mineral salt medium (MSM) were as follow [22]: $\left(\mathrm{NH}_{4}\right)_{2} \mathrm{SO}_{4} 2 \mathrm{~g}, \mathrm{~K}_{2} \mathrm{HPO}_{4}$ $1.6 \mathrm{~g}, \mathrm{KH}_{2} \mathrm{PO}_{4} 0.8 \mathrm{~g}, \mathrm{MgSO}_{4} \cdot 7 \mathrm{H}_{2} \mathrm{O} 1.0 \mathrm{~g}, \mathrm{CaCl}_{2} 0.125 \mathrm{~g}, \mathrm{ZnSO}_{4} \cdot 7 \mathrm{H}_{2} \mathrm{O} 0.06 \mathrm{~g}, \mathrm{MnSO}_{4} 0.0375 \mathrm{~g}, \mathrm{H}_{3} \mathrm{BO}_{3}$ $0.0225 \mathrm{~g}, \mathrm{NiCl}_{2} 0.018 \mathrm{~g}, \mathrm{CoCl}_{2} 0.014 \mathrm{~g},\left(\mathrm{NH}_{4}\right)_{6} \cdot \mathrm{Mo}_{7} \mathrm{O}_{24} \cdot 4 \mathrm{H}_{2} \mathrm{O} 0.0134 \mathrm{~g}, \mathrm{FeCl}_{3} 0.003 \mathrm{~g}, \mathrm{CuSO}_{4} \cdot 5 \mathrm{H}_{2} \mathrm{O}$ $0.0025 \mathrm{~g}$, Deionized Water $1000 \mathrm{~mL}$ and the $p \mathrm{H}$ was $6.7 \pm 0.05$. All the chemicals were of analytical grade. Before the experiment, the MSM was autoclaved for 15 min.

\subsubsection{Inoculum}

The activated sludge was taken from the aeration tank of a municipal sewage treatment plant in Shandong Qingdao, China. The activated sludge was aerated for $24 \mathrm{~h}$ to improve the activity of the microorganisms. The sludge was allowed to sit for $20 \mathrm{~min}$ and the supernatant was removed to increase the sludge concentration. The concentrated sludge was stored at $4^{\circ} \mathrm{C}$ before use. The activated sludge was added to MSM. The acrylic paint thinner was used as the sole carbon source and added regularly. 
The inoculum was incubated by the shaker at $150 \mathrm{rpm}$ for 10 days at $30^{\circ} \mathrm{C}$ before starting the experiment.

\subsubsection{Acrylic paint thinner composition and simulated exhaust gas}

The acrylic paint thinner was self-configured by the laboratory, and it is mainly composed of 50\% toluene, $30 \%$ ethylbenzene, $10 \%$ m-xylene and $10 \%$ o-xylene.

The organic components in the simulated exhaust gas were measured by a gas chromatograph (GC2014C, Shimadzu) equipped with a flame ionization detector (FID). Figure 1 and Table 1 showed the detection in the simulated exhaust gas of acrylic paint thinner.

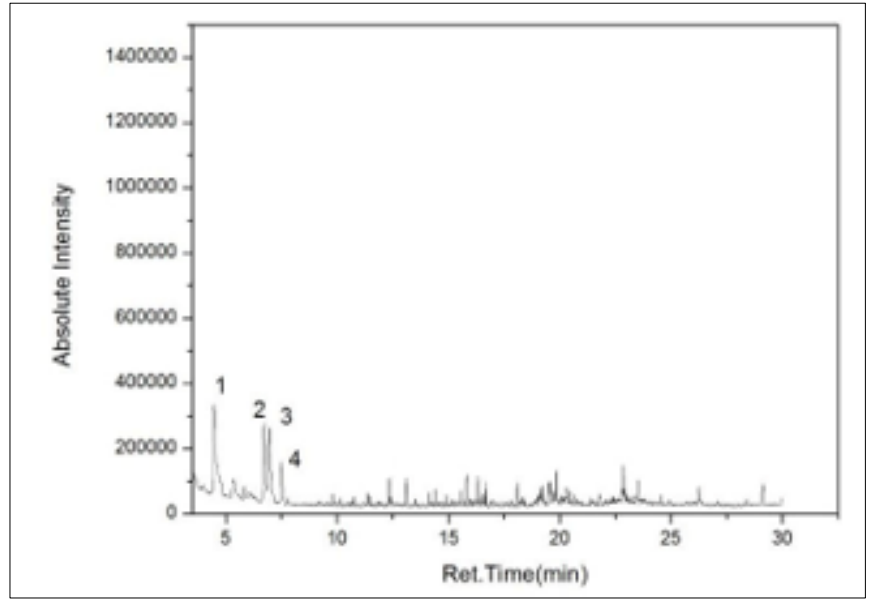

Figure 1. Chromatogram of acrylic paint thinner exhaust gas

Table 1. Composition of acrylic paint thinner exhaust gas

\begin{tabular}{|c|c|c|c|c|}
\hline Peak sign & Name & Molecular formula & Structure & $50 \pm 3 \%$ \\
\hline 1 & Toluene & $\mathrm{C}_{7} \mathrm{H}_{8}$ & \\
\hline 2 & Ethylbenzene & $\mathrm{C}_{8} \mathrm{H}_{10}$ & $30 \pm 5 \%$ \\
\hline 3 & m-xylene & $\mathrm{C}_{8} \mathrm{H}_{10}$ & $10 \pm 2 \%$ \\
\hline 4 & o-xylene & $\mathrm{C}_{8} \mathrm{H}_{10}$ & & $10 \pm 3 \%$ \\
\hline
\end{tabular}

\subsection{Experimental device and method}

As shown in Figure 2, the BTF used in this experiment was a combination of plexiglass columns and a culture tank. The BTF had six layers, each with a height of $30 \mathrm{~cm}$ and an inner diameter of $20 \mathrm{~cm}$. The uppermost layer was equipped with sprinklers, and the lower five layers were filled in fillers (volcanic rocks, Particle size 20-30 mm, Porosity $64 \%$, Bulk density $0.25-0.30 \mathrm{~g} / \mathrm{cm}^{3}$ ) with a height of $20 \mathrm{~cm}$. The bottom of each layer was separated by a stainless-steel screen to support the fillers thereon. The bottom of the BTF was equipped with a cone-shaped airflow distributor. Sampling ports were equipped at the junction of each layer, the inlet and outlet ports of the BTF. Simulated exhaust gas was generated by purging the target contaminant with an air pump. Both air and simulated exhaust gas were blown into the turbulent mixer. The purge flow rates and mixed exhaust gas flow rates were controlled by two mass flow controllers to adjust different EBRTs. The mixed gas entered the BTF from the bottom of the tower, and discharged from the top of the tower after being adsorbed and removed by the biofilm. A water pump was used to lift the bacterial liquid to the top of the BTF to form a counter current mode with the gas flow and the bacterial liquid then returns to the culture tank from the bottom of the tower. There was 
a constant temperature heating control system in the bacterial liquid culture tank, which could maintain the temperature of the bacterial liquid at about $25^{\circ} \mathrm{C}$.

In the initial stage of adding inoculum, a lower concentration of simulated waste gas was introduced, and the bacteria-containing liquid was continuously sprayed. At the same time, the concentration of toluene, ethylbenzene, m-xylene and o-xylene in the treated gas was detected. When the concentration of outgas no longer changed, gradually increased the simulated exhaust gas concentration in the intake air and continuously changed the intake air load until a stable biofilm can be observed.

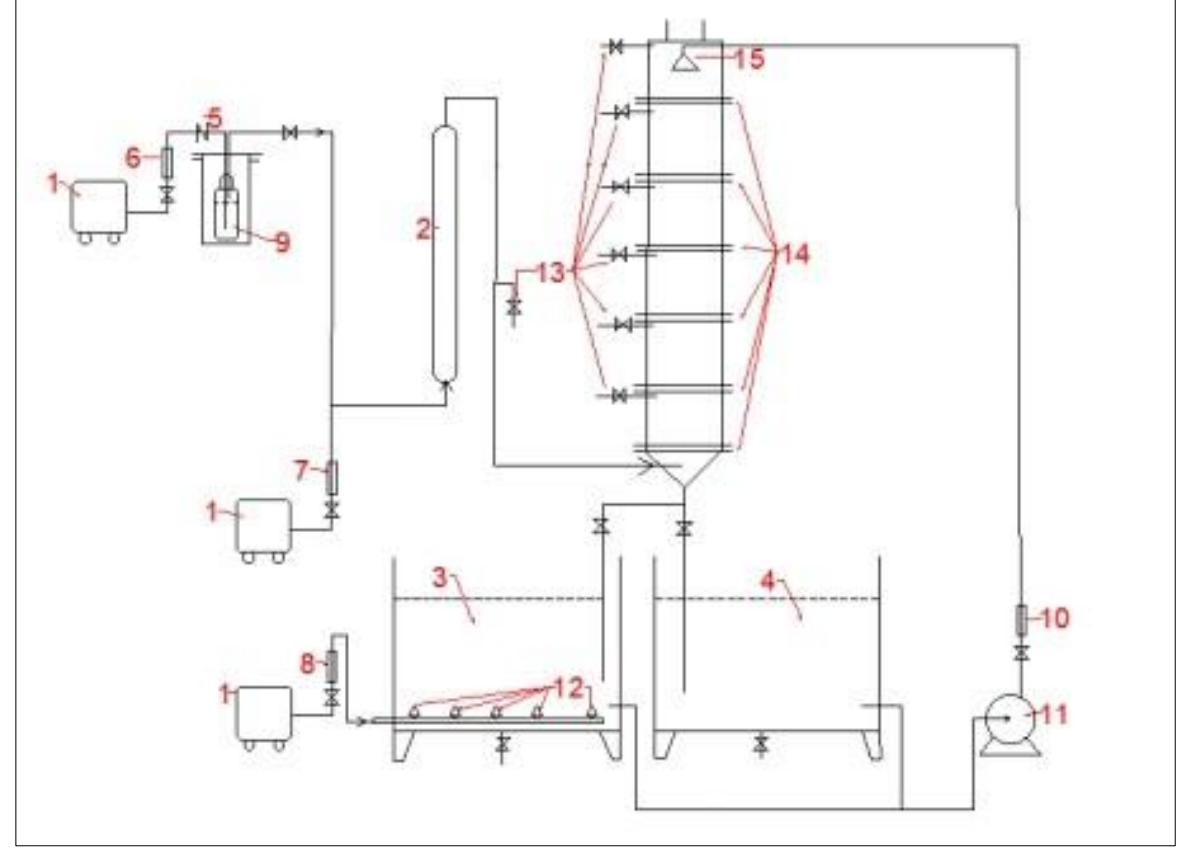

Figure 2. Flow chart of experimental device for BTF.

(1. Air pump; 2. Turbulent mixer (Shanghai Xinruidu, Length of $100 \mathrm{~cm}$, diameter of $5.5 \mathrm{~cm}$ );

3. Culture tank of bacterial liquid (100L); 4. Absorbing liquid tank (100L); 5. Check valve;

6. Flowmeter $(0.1-1 \mathrm{~L} / \mathrm{min}) ; 7$. Flowmeter $\left(0.4-4 \mathrm{~m}^{3} / \mathrm{h}\right) ; 8$. Flowmeter $(5 \mathrm{~L} / \mathrm{min})$;

9. The gas generator; 10. Flowmeter $(1-10 \mathrm{~L} / \mathrm{min}) ; 11$. Water pump; 12. Aerator;

13. Sampling ports; 14. Flange; 15. Spray header)

\subsection{Performance evaluation}

The performance of the BTF was evaluated in terms of the removal efficiency (RE, \%), the empty bed residence time (EBRT, s) and the elimination capacities $\left(E C, \mathrm{~g} \mathrm{~m}^{-3} \mathrm{~h}^{-1}\right)$, which were estimated using the following equations:

$$
\begin{aligned}
& R E=\left(1-C_{\text {out }} / C_{\text {in }}\right) \cdot 100 \\
& E B R T=V / Q \cdot 3600 \\
& E C=\left(C_{\text {in }}-C_{\text {out }}\right) \cdot Q / 1000 \mathrm{~V}
\end{aligned}
$$

where $C_{\text {in }}$ is the inlet concentration, $\mathrm{mg} \cdot \mathrm{m}^{-3} ; C_{\text {out }}$ is the outlet concentration, $\mathrm{mg} \cdot \mathrm{m}^{-3} ; Q$ is the gas flow, $\mathrm{m}^{3} \cdot \mathrm{h}^{-1}$; and $V$ is the volume of the biofilter, $\mathrm{m}^{3}$.

\subsection{Analytical methods}

Acrylic paint thinner concentrations in the gas phase were analyzed in a gas chromatograph (GC2014C, Shimadzu) equipped with a flame ionization detector and an Inert Cap FFAP $(30 \mathrm{~m} \times 0.25 \mathrm{~mm}$ $\times 0.25 \mu \mathrm{m}$ ) capillary column. The oven temperature was initially maintained at $50^{\circ} \mathrm{C}$ for $1 \mathrm{~min}$, increased at $50^{\circ} \mathrm{C} \mathrm{min}{ }^{-1}$ up to $70^{\circ} \mathrm{C}$ and then at $65^{\circ} \mathrm{C} \mathrm{min}^{-1}$ to a final temperature of $140^{\circ} \mathrm{C}$. All the data obtained were the average of three tests. 
After a period of stable operation, the two phases of liquid (bacterial liquid) and solid (volcanic rock) were sampled to explore the mechanism of microbial degradation. The liquid and the solid samples were pretreated by n-hexane extraction, and come from the organic matter attached to the bacterial liquid tank and the volcanic rock, respectively. All samples were analyzed by GC-MS (GCMS-QP2010, Shimadzu, Japan). Samples for the determination of the concentration of TOC in the liquid phase were measured using a Shimadzu TOC-VCSH analyzer (Japan) coupled. Biomass concentration was estimated as VSS according to Standard Methods. More specifically, a $50 \mathrm{~mL}$ sample was filtered in a pre-dried and preweighted filter $(1 \mu \mathrm{m}$ pore size $)$ and evaporated for $24 \mathrm{~h}$ at $105^{\circ} \mathrm{C}$. The corresponding residue was weighted and further dried in a furnace at $550^{\circ} \mathrm{C}$ for another $24 \mathrm{~h}$. The amount of VSS was determined from the resulting solid after combustion.

\subsection{Microbial analysis}

High-throughput sequencing of $16 \mathrm{~S}$ rDNA amplicon was used to investigate the microbial communities in the BTF. After the BTF had successfully run and had reached a relatively stable treatment efficiency, the bacterial liquid in the bacterial liquid culture tank was mixed with the phosphate solution and then be centrifuged (8000 rpm, $10 \mathrm{~min}$ ) [23]. The genomic DNA (gDNA) was extracted from the pellets using a DNA isolation kit (Shanghai Biological Engineering Co., Ltd.). The gDNA quality and density were examined using a NanoDrop spectrometer. The PCR program included an initial denaturation at $94^{\circ} \mathrm{C}$ for $4 \mathrm{~min}$, afterward 32 cycles of $94^{\circ} \mathrm{C}$ for $20 \mathrm{~s}, 57^{\circ} \mathrm{C}$ for $25 \mathrm{~s}$ and $68^{\circ} \mathrm{C}$ for $45 \mathrm{~s}$, and a final extension at $72^{\circ} \mathrm{C}$ for $10 \mathrm{~min}$. PCR products were examined on a $1 \%(\mathrm{w} / \mathrm{v}) \mathrm{TAE}-$ agarose gel from where the bands with expected size were excised and recovered. The fragment library was constructed with the VAHTSTM Nano DNA Library Prep Kit for Illumina (Vazyme Biotech Co., Ltd.). The sequencing platform was Illumina1 MiSeq PE300.

The fatty acid identification system was mainly used to analyze and identify microorganisms that had been isolated and purified in the artificial media. The steps of the extraction of fatty acids were as follow steps: saponification, methylation, extraction, alkaline washing, and transfer of the extract to the sample vial. The specific operation steps could refer to the MIDI fatty acid extraction steps [24]. The sample vials were analyzed with the gas chromatography (GC6850, Agilent) equipped with a flame ionization detector (FID), and an Agilent 19091B.102 chromatographic column $(25.0 \mathrm{~m} \times 200 \mathrm{um} \times 0.33$ um).

Separation and count of bacteria was performed according to the conventional dilution plate count described by Chen and Zhang [25].

\section{Results and discussions}

\subsection{The effect of inlet concentration}

Under the conditions of liquid recycling velocity of $15.92 \mathrm{~m} \mathrm{~h}^{-1}$, the EBRT of $50.24 \mathrm{~s}$ and $75.36 \mathrm{~s}$, the different inlet concentration of simulated exhaust gas was injected to the BTF, and its influence on the RE and EC were observed. In Figure 3, it could be seen that when the inlet concentration increased, the RE decreased, the EC increased [26]. In addition, the RE of the EBRT(a) was about $20 \%$ higher than that of the EBRT(b) at the same inlet concentration, with the corresponding ECs of $16.71 \pm 2.32 \mathrm{~g}$ $\mathrm{m}^{-3} \mathrm{~h}^{-1}$ and $18.09 \pm 1.98 \mathrm{~g} \mathrm{~m}^{-3} \mathrm{~h}^{-1}$, respectively. This was because the increase in residence time promoted the diffusion of pollutants to the biofilm, thereby it could increase the RE [27]. When the EBRT(b) was $75.36 \mathrm{~s}$, the inlet concentration was in the range of $59-1125 \mathrm{mg} / \mathrm{m}^{3}$, the corresponding RE decreased from $85.31 \%$ to $64.90 \%$. And, when the inlet concentration was less than $500 \mathrm{mg} / \mathrm{m}^{3}$, the RE was greater than $70 \%$. When the EBRT(a) was $50.24 \mathrm{~s}$, the inlet concentration was in the range of $90.63-706 \mathrm{mg} / \mathrm{m}^{3}$, the corresponding RE decreased from $58.40 \%$ to $51.59 \%$. This was because that the transferred pollutants from the gas phase to the surface of the biofilm were affected by diffusion restrictions, so only part of the pollutants could enter the biofilm and be degraded. It also may be due to the high concentrations of simulated exhaust gas inhibit the metabolic activity of the bacterial growth on the fillers [28]. It can be concluded that when the EBRT was less than 75s, the removal was not well, and 
the highest RE was only $58.4 \%$. Therefore, the subsequent experiments adopted the EBRT started from $75 \mathrm{~s}$.

\subsection{The effect of the EBRT}

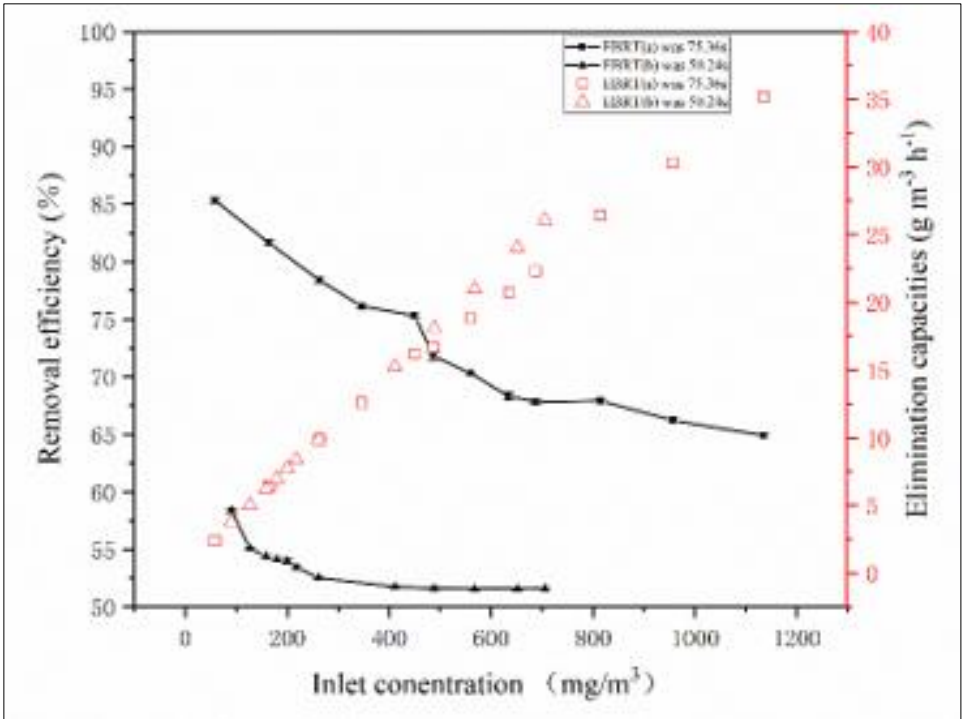

Figure 3. The effect of inlet concentration on the removal efficiency and elimination capacities of acrylic paint thinner when the EBRT of 50.24s and 75.36s

In this experiment, the selection of the EBRT started from $75 \mathrm{~s}$. When liquid recycling velocity remained at $15.92 \mathrm{~m} \mathrm{~h}^{-1}$, the EBRTs influence on the RE and EC under different inlet concentrations was shown in Figure 4 and Figure 5. It could be seen that as EBRT increases, RE increased and EC decreased. When the EBRT was less than 150s, this trend was obvious. But when the EBRT was higher than 150s, the growth trend of the RE gradually slowed down. This was because when the EBRT was less than 150s, the increase of the RE was mainly limited by diffusion. With the increase of the EBRT ( $\geqq 150$ s), the diffusion limitation gradually became insignificant and the system was limited only by microbial activity and reaction [29]. When the EBRT was greater than $300 \mathrm{~s}$, the REs were all above $90 \%$, corresponding to ECs of $8.36 \pm 4.07 \mathrm{~g} \mathrm{~m}^{-3} \mathrm{~h}^{-1}$. Among them, the removal efficiency of toluene and ethylbenzene was above $95 \%$, and the xylene (m-xylene, o-xylene) could reach more than $70 \%$, corresponding to elimination capacities (ECs) of $3.02 \pm 0.33 \mathrm{~g} \mathrm{~m}^{-3} \mathrm{~h}^{-1}, 1.81 \pm 0.2 \mathrm{~g} \mathrm{~m}^{-3} \mathrm{~h}^{-1}, 0.60 \pm 0.07 \mathrm{~g}$ $\mathrm{m}^{-3} \mathrm{~h}^{-1}$, respectively. When the EBRT was the same, the RE of the lower inlet concentration was higher than that of the higher inlet concentration. The conclusion was also similar to chapter 3.1.

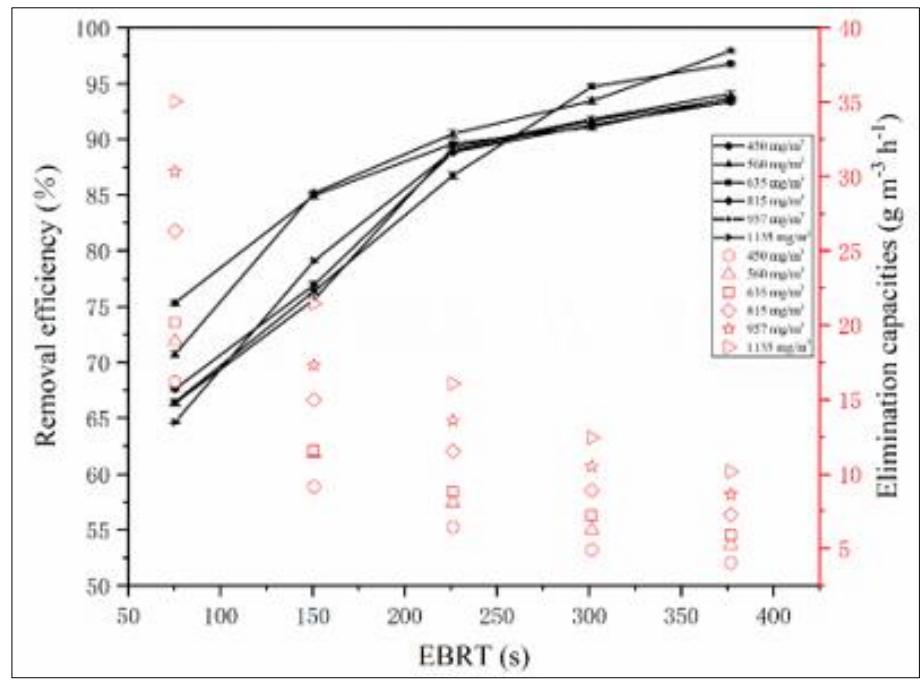

Figure 4. The effect of the EBRT on the removal efficiency and elimination capacities of acrylic paint thinner under different inlet concentration 


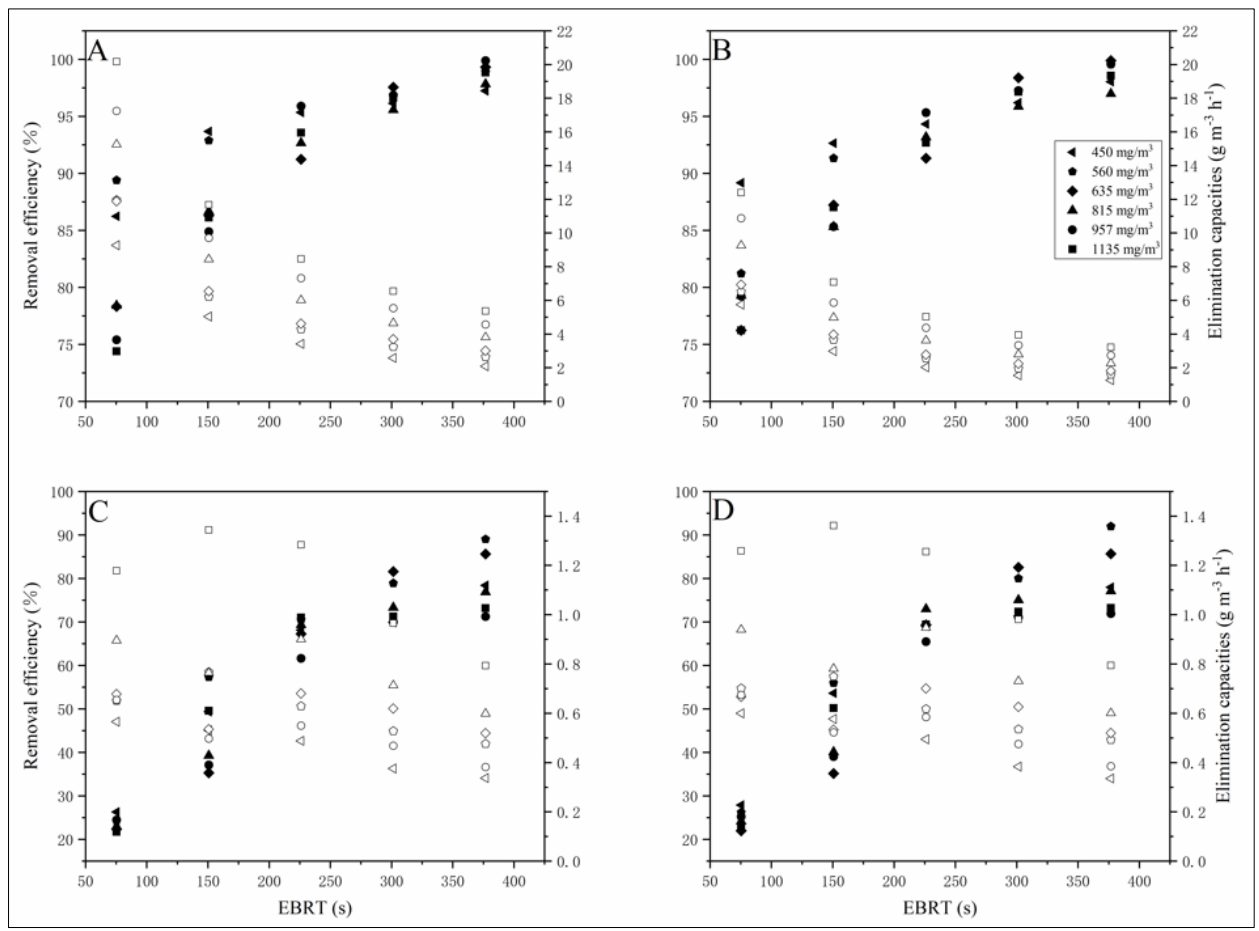

Figure 5. Time course of toluene (A), ethylbenzene (B), m-xylene (C) and o-xylene (D) removal efficiency (solid) and elimination capacities (hollow)

\subsection{The effect of spraying volume}

Under the condition of inlet concentration of $450 \mathrm{mg} / \mathrm{m}^{3}$ and the different EBRT, the liquid recycling velocity was changed to observe its influence on the RE and EC. As Figure 6 shown, during the increase of the liquid recycling velocity, the RE and EC presented a trend of rising first and then falling, but the overall fluctuation range was not obvious. In the range of $12.73-38.20 \mathrm{~m} \mathrm{~h}^{-1}$, the RE was maintained at $75 \%$ or more. The best removal efficiency was achieved under the liquid recycling velocity of $25.46 \mathrm{~m}$ $\mathrm{h}^{-1}$. Due to the film thickness, gas-liquid contact area and biomass increased with the increase in liquid recycling velocity, therefore, the RE increased. But when the liquid recycling velocity was too large, it would have a certain impact on the mass transfer and adsorption of organic matter into the liquid membrane and biofilm, it led to the RE decrease [30].

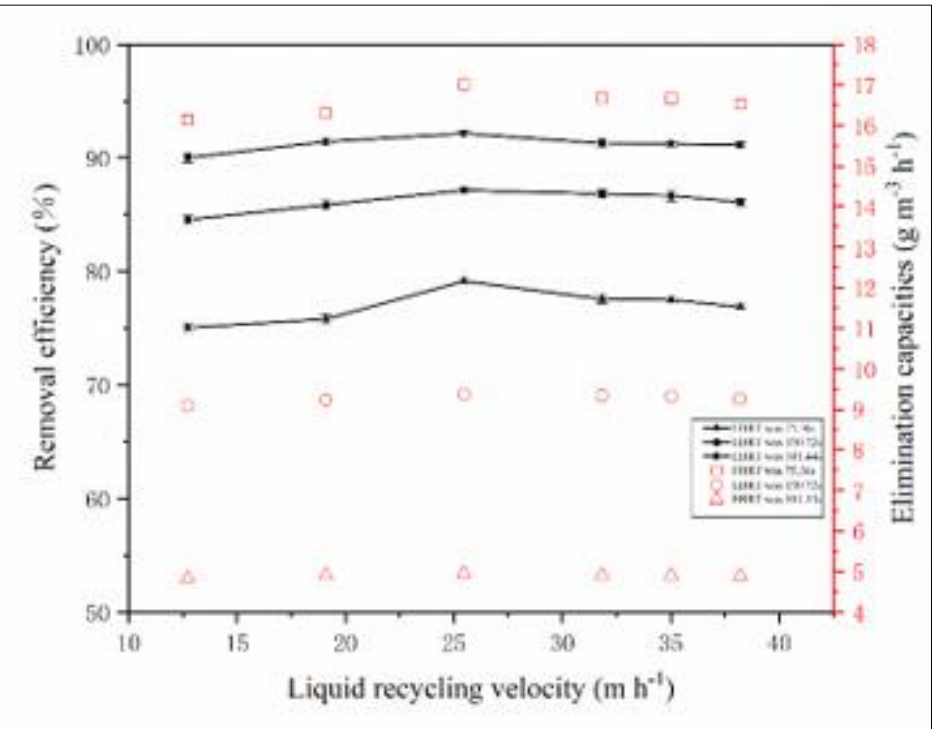

Figure 6. The effect of the spraying volume on the removal efficiency and elimination capacities of acrylic paint thinner 


\subsection{Microbial degradation pathway analysis}

The four dominant bacteria selected from the experiment were identified by fatty acid identification (Table 2) and 16SrDNA Sequencing (Table 3). The four dominant bacteria were Bacillus cereus, Bacillus subtilis, Acinetobacter calcoaceticus and Belem Bacillus, respectively. Figure 7 showed that each running belt was clear and bright, indicating that the DNA extraction was successful, and the amplified fragments had good purity and completeness. From the identification results (Table 2, Table 3 ), it can be seen that the results obtained by the two identification methods were almost identical, indicating that both methods had high reliability and the strains had high purity [31,32]. The total average of the bacteria in the biofilm was $3.12 \times 10^{8} \mathrm{CFU} / \mathrm{g} \mathrm{TS}$, which was $32.2 \%$ higher than that of the control (the culture of microbes prior to the inoculation of acrylic paint thinner degrading microbes).

Table 2. Result of fatty acid identification

\begin{tabular}{|c|c|c|}
\hline Peak sign & Sim Index & Name \\
\hline 1 & 0.60 & Bacillus-cereus-GC subgroup A \\
\hline 2 & 0.87 & Bacillus-subtilis \\
\hline 3 & 0.78 & Acinetobacter-calcoaceticus \\
\hline 4 & 0.62 & Bacillusvelezensis \\
\hline
\end{tabular}

Table 3. 16SrDNA identification results

\begin{tabular}{|c|c|}
\hline Peak sign & Name \\
\hline 1 & Bacillus-cereus \\
\hline 2 & Bacillus-subtilis \\
\hline 3 & Acinetobacter-calcoaceticus \\
\hline 4 & Bacillus velezensis \\
\hline
\end{tabular}

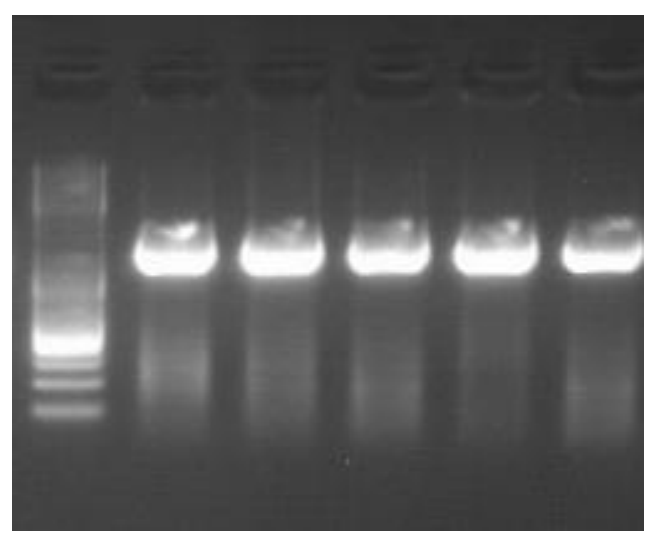

Figure 7. The result of electrophoresis

After testing, there were no intermediate products in the gas and solid phases. According to Figure 8 and Table 4, a total of six organic components were detected in the bacterial solution, belonging to three categories of organics: ketone, alcohol and organic peroxides, respectively. 


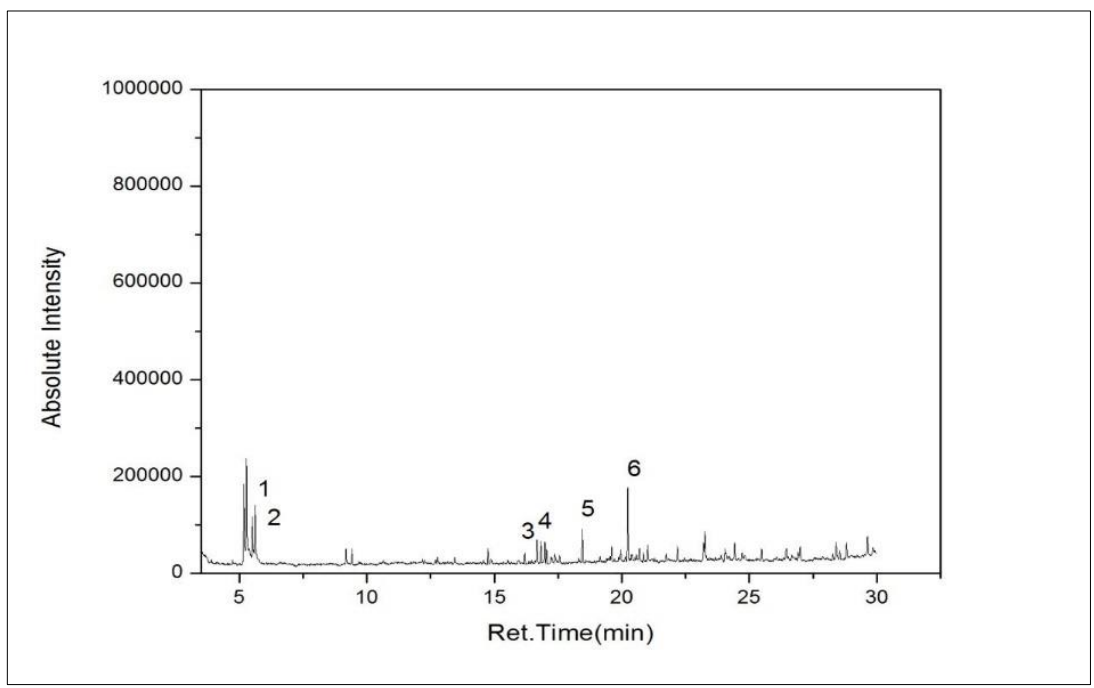

Figure 8. Chromatogram of the bacteria liquid for handling acrylic paint thinner

Table 4. Composition of the bacteria liquid

\begin{tabular}{|c|c|c|c|}
\hline Peak sign & Name & Molecular formula & Structure \\
\hline 1 & 3-Hexanone & $\mathrm{C}_{6} \mathrm{H}_{12} \mathrm{O}$ & 0 \\
\hline 2 & 2-Hexanone & $\mathrm{C}_{6} \mathrm{H}_{12} \mathrm{O}$ & \\
\hline 3 & 3-Hexanol & $\mathrm{C}_{6} \mathrm{H}_{13} \mathrm{OH}$ & $\mathrm{OH}$ \\
\hline 4 & 2-Hexanol & $\mathrm{C}_{6} \mathrm{H}_{13} \mathrm{OH}$ & \\
\hline 5 & 1-ethylbutyl, Hydroperoxide & $\mathrm{C}_{6} \mathrm{H}_{14} \mathrm{O}_{2}$ & \\
\hline 6 & 1-methylpentyl, Hydroperoxide & $\mathrm{C}_{6} \mathrm{H}_{14} \mathrm{O}_{2}$ & \\
\hline
\end{tabular}

The Bacillus cereus can produce 2,3-catechol dioxygenase and toluene monooxygenase [33]; Bacillus subtilis can produce carbonyl reductase [34]; Acinetobacter calcoaceticus can produce toluene monooxygenase [35], toluene dioxygenase [36] and 2,3-catechol dioxygenase [37].

Degradation of toluene in aerobic conditions could be divided into three ways:

(1) Catalyzed by toluene monooxygenase to hydroxylate the methyl group part;

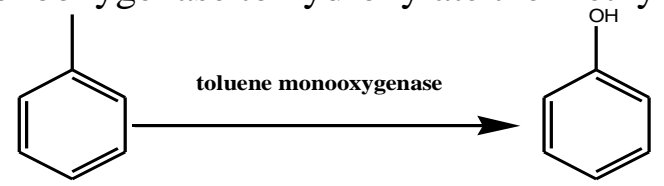

(2) Catalyzed by different toluene monooxygenases, hydroxylated at the ortho-, meta- and para-position of the aromatic nucleus;

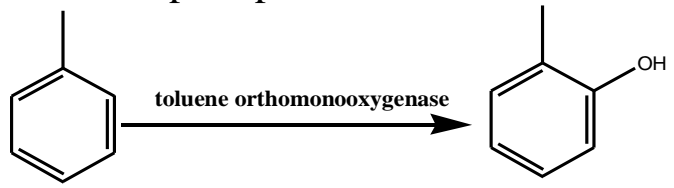




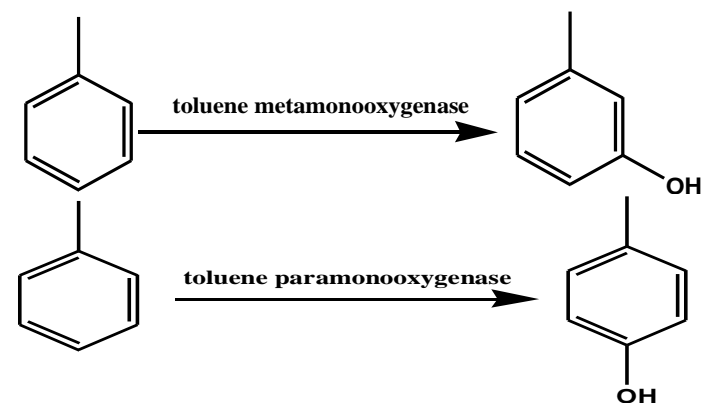

(3) Catalyzed by toluene dioxygenase, the aromatic nucleus was double-hydroxylated

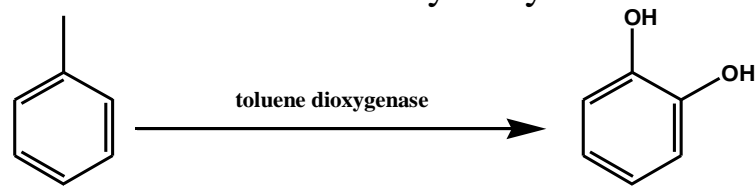

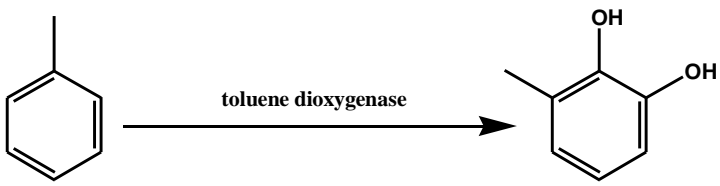

Based on the analysis results of the degradation product components of the above-simulated exhaust gas, can draw that the benzene ring was cracked, and then alcohols and ketones are formed through redox reactions [38].

It was speculated that the possible reaction pathways were as follows: toluene, xylene and ethylbenzene could be converted into phenol or catechol under the action of toluene monooxygenase or toluene dioxygenase. Moreover, phenol would further produce catechol after the adjacent hydroxylation reaction. During the degradation of aromatic compounds, catechol was an important intermediate product. Under the action of catechol dioxygenase, the benzene ring of catechol was fissioned to produce ketones or alcohols. Among them, carbonyl reductase also could convert ketones into alcohols. The presence of two hydroxyl groups on the aromatic nucleus is a general prerequisite for ring cleavage and further reactions [39]. Taken toluene as an example, the possible degradation pathways were speculated as follows (Figure 9):

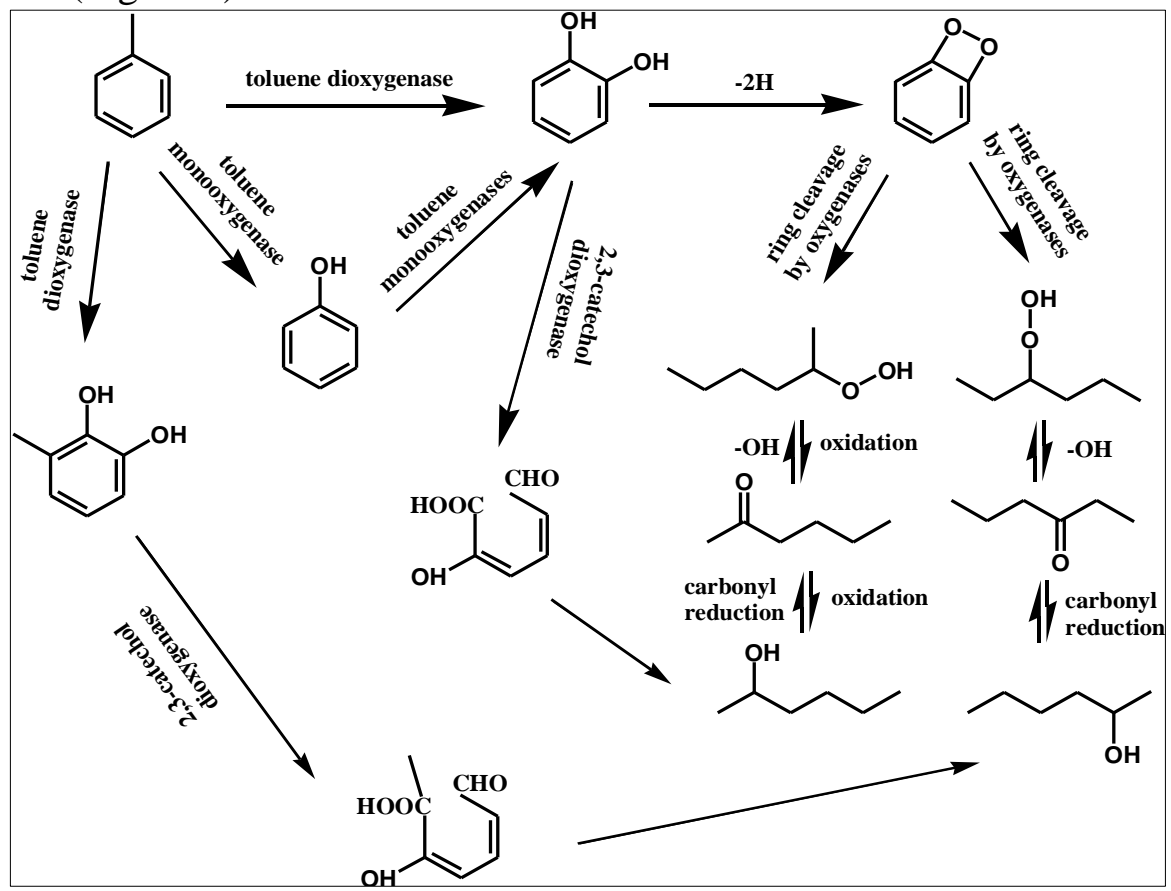

Figure 9. Biodegradation pathway of toluene 


\subsection{Kinetics analysis}

\subsubsection{Absorption-biofilm theory and its kinetic model}

Dutch scholar Ottengraf [19] absorption-biofilm theory based on the traditional two-film theory of absorption operations. The volatile organic compounds in the gas phase contacted the gas film, and then diffused from the gas film into the liquid film. Under the action of the concentration gradient, the organic compounds dissolved in the liquid film further diffused to the biofilm and was adsorbed by the wet biofilm surface. The bacteria quickly captured the organic matter as a carbon source. As energy and nutrients, organic matter participated in the metabolic activities of bacteria, and was decomposed into small molecular compounds. According to the adsorption-biofilm theory, the general steps of biochemical degradation of organic exhaust gas were shown in Figure 10.

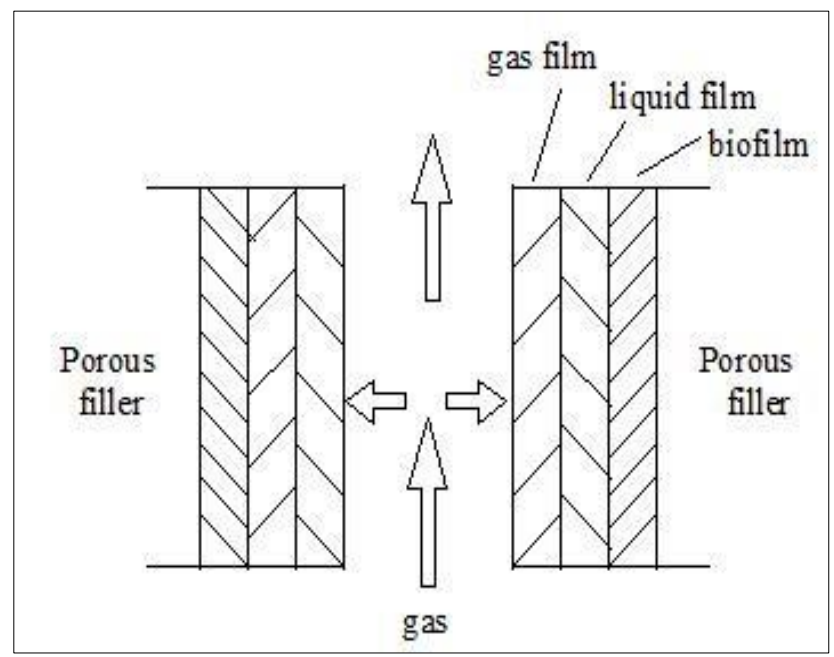

Figure 10. Microcell model schematic of biodegradation of exhaust gas

The absorption-biofilm theory states, the concentration distribution of pollutants at the gas filmliquid film interface follows Henry's law. The formula for estimating the toluene concentration in the outlet gas from the liquid film -biofilm was as follows:

$$
\begin{gathered}
C_{\text {gout }}=C_{l} \times H_{c}+\left(C_{\text {gin }}-C_{l} \times H_{C}\right) \times(1-W) \\
C_{\text {gout }}=C_{\text {gin }}-K_{1 a} \times C_{l} \times a \times \frac{V}{Q}
\end{gathered}
$$

The calculation formula of the toluene concentration $C_{l}$ of the circulating liquid is:

Intermediate quantity:

$$
C_{l}=\frac{C_{g i n} \times W}{K_{1 a} \times a \times T_{n}+H_{c} \times W}
$$

$$
W=1-\exp \left(-\frac{K_{L} \times T_{n}}{H_{c}}\right)
$$

In the formula: $H_{c}$-Henry Constant; $\left(H_{c}=C_{g} / C_{l}\right)$;

$K_{1 a}$-First-order biochemical reaction rate constant $(\mathrm{m} / \mathrm{h})$;

$K_{L}$-Physical absorption liquid film mass transfer coefficient $(\mathrm{m} / \mathrm{s})$;

$a$-Specific surface area of filler $\left(\mathrm{m}^{2} / \mathrm{m}^{3}\right)$;

$T_{n}$-Gas residence time in the packing layer (s);

$V$-Packing layer volume $\left(\mathrm{m}^{3}\right), \mathrm{V}=\mathrm{S} \times \mathrm{H}$;

$\mathrm{Q}$-Gas flow (L/min); 
The zero-level biochemical reaction zone. According to the above method, the formula of the toluene concentration of the outlet gas can be derived:

$$
C_{g}=C_{g i n}-K_{0} \cdot a \cdot s \cdot \frac{H}{Q}
$$

In the formula: $K_{0}$-Zero-order biochemical reaction rate constant $(\mathrm{m} / \mathrm{h})$;

$H$-Media height (m);

$S$-Filler cross-sectional area $\left(\mathrm{m}^{2}\right)$;

$$
\text { Make } \mathrm{A}=\mathrm{k}_{0} \cdot \mathrm{a} \cdot \mathrm{s} \text {, then } C_{g}=C_{g i n}-A \frac{H}{Q}
$$

when Q was constant, the change of toluene concentration at the different heights of the filler was shown in Figure 11. From the fitting effect (Table 5), when the inlet concentration was greater than $500 \mathrm{mg} / \mathrm{m}^{3}$, $\mathrm{R}^{2}$ values were all above 0.96 . When the inlet concentration was less than $500 \mathrm{mg} / \mathrm{m}^{3}$, the average value of $\mathrm{R}^{2}$ was around 0.86 , and the simulation effect was not ideal. It indicated that the model was appropriate for the treatment of toluene at higher inlet concentrations.

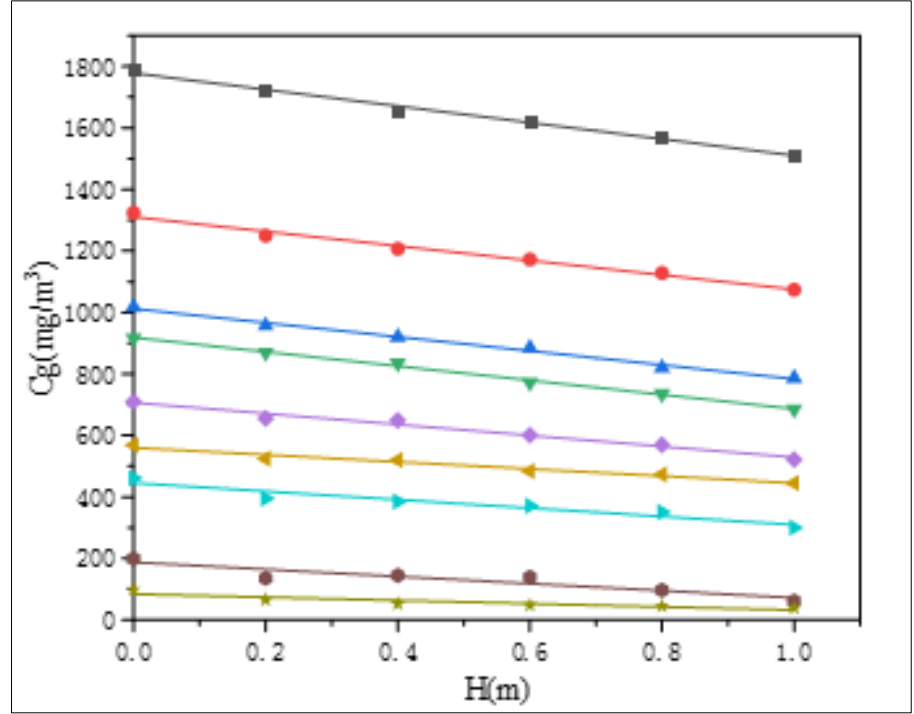

Figure 11. The fitting curve of the distribution of the concentration of toluene along with the height of filler with a different inlet concentration

\begin{tabular}{|c|c|c|c|}
\hline Parameter & Value & Standard Error & $\mathbf{R}^{2}$ \\
\hline a1 & 1778.12 & 7.02 & \multirow{2}{*}{0.99} \\
\hline $\mathrm{b} 1$ & -268.14 & 11.60 & \\
\hline a2 & 1310.33 & 8.08 & \multirow{2}{*}{0.99} \\
\hline b2 & -235.70 & 13.35 & \\
\hline a3 & 1012.00 & 6.33 & \multirow{2}{*}{0.99} \\
\hline b3 & -228.56 & 10.45 & \\
\hline $\mathrm{a} 4$ & 918.20 & 4.45 & \multirow{2}{*}{0.99} \\
\hline b4 & -231.84 & 7.36 & \\
\hline a5 & 706.83 & 8.23 & \multirow{2}{*}{0.98} \\
\hline b5 & -178.12 & 13.60 & \\
\hline a6 & 560.08 & 6.70 & \multirow{2}{*}{0.96} \\
\hline b6 & -115.05 & 11.07 & \\
\hline a7 & 445.38 & 12.35 & \multirow{2}{*}{0.92} \\
\hline b7 & -136.05 & 20.39 & \\
\hline a8 & 187.73 & 13.96 & \multirow{2}{*}{0.86} \\
\hline $\mathrm{b} 8$ & -115.75 & 23.06 & \\
\hline a9 & 84.28 & 7.90 & \multirow{2}{*}{0.80} \\
\hline b9 & -51.99 & 13.04 & \\
\hline
\end{tabular}

Table 5. Data obtained from the fitting results 
The equation is $y=a+b * x, \mathrm{y}$ is $\mathrm{C}_{\mathrm{g}}, \mathrm{x}$ is $\mathrm{H}$, $\mathrm{a}$ is $\mathrm{C}_{\mathrm{gin}}, \mathrm{b}$ is $-\mathrm{A} / \mathrm{Q}$, the a1-a9 in the table correspond to high concentration to a low concentration in order.

Under different inlet concentrations, the values of -A/Q and A were shown in Table 6.

Table 6. The A value obtained by substituting experimental data

\begin{tabular}{|c|c|c|c|}
\hline Inlet concentration $\left(\mathbf{m g} / \mathbf{m}^{\mathbf{3}}\right)$ & $\mathbf{Q}(\mathbf{L} / \mathbf{m i n})$ & $\mathbf{- A} / \mathbf{Q}$ & $\mathbf{A}$ \\
\hline 1787.33 & 30 & -268.14 & 8044.20 \\
\hline 1323.86 & 30 & -235.70 & 7041 \\
\hline 1017.71 & 30 & -228.56 & 6856.80 \\
\hline 916.45 & 30 & -231.84 & 6955.20 \\
\hline 709.86 & 30 & -178.12 & 5343.60 \\
\hline 568.32 & 30 & -115.05 & 3451.50 \\
\hline 461.29 & 30 & -136.05 & 4081.50 \\
\hline 199.35 & 30 & -115.75 & 3472.50 \\
\hline 98.80 & 30 & -51.99 & 1559.70 \\
\hline
\end{tabular}

Validation of the model at higher inlet concentrations $\left(\geqq 500 \mathrm{mg} / \mathrm{m}^{3}\right)$

$$
\text { Taken } \mathrm{A}=7000 \text {, then } C_{g}=C_{g i n}-7000 \frac{H}{Q}
$$

When $\mathrm{Q}$ was $30 \mathrm{~L} / \mathrm{min}$ and $\mathrm{H}$ was $0.2 \mathrm{~m}$ high, the experimental data was obtained under different inlet concentration conditions were substituted into the verification model (10), and the results were shown in Figure 12. At a higher inlet concentration $\left(\geqq 500 \mathrm{mg} / \mathrm{m}^{3}\right)$, the correlation coefficient between the experimental data and the calculated data was 0.9998, indicating that the model was suitable.

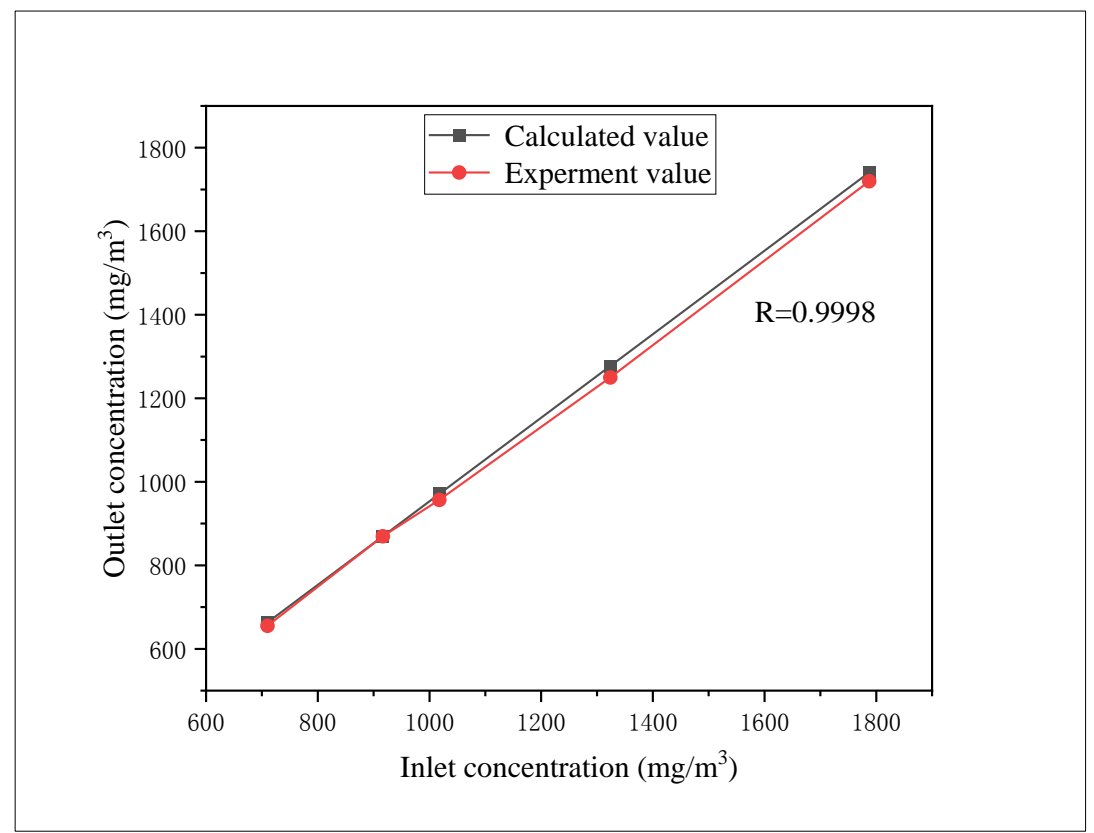

Figure 12. Comparing the result calculated by the model with experimental result for the outlet concentration of toluene

\subsubsection{Adsorption-biofilm theory and its kinetic model}

The adsorption-biofilm theory proposed by Sun Peishi [21] improved the degradation process of VOCs at low concentrations. The volatile organic compounds in the gas phase contacted the gas film, 
then it diffused to the wet biofilm surface, the bacteria adsorbed them. Then the organic matter participates as energy and nutrients were decomposed by metabolic activity in the bacteria. According to the adsorption-biofilm theory, the existence of liquid film was ignored. The biochemical method of degrading low-concentration organic exhaust gas were shown in Figure 13.

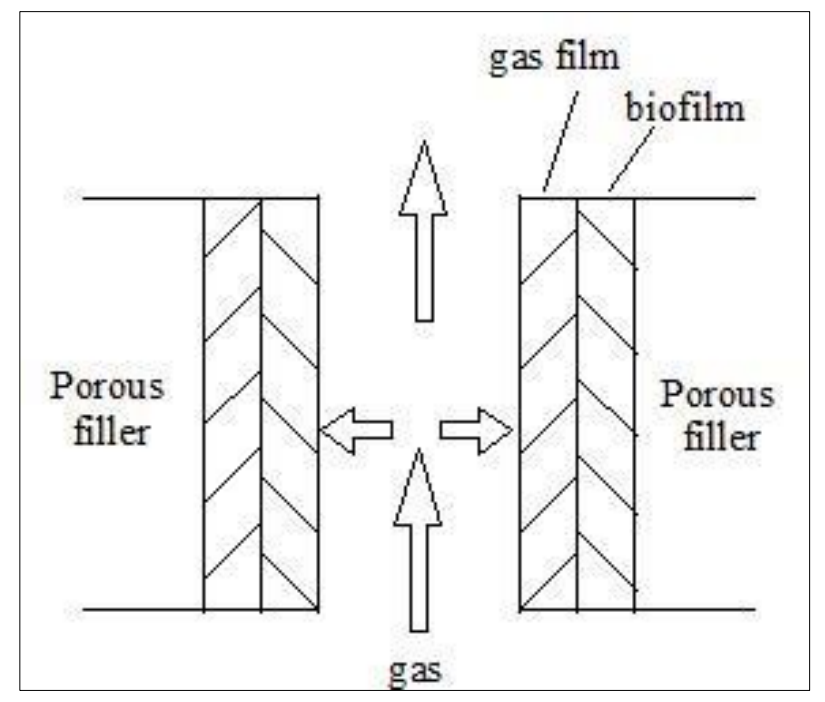

Figure 13. Microcell schematic of biodegradation of exhaust gas

Due to the neglect of the existence of liquid film, the adsorbed-biofilms theory had been simplified to a certain extent, greatly reducing the complexity of the derivation and calculation process. The simplified model believed that the concentration distribution of toluene in the gas phase was always uniform. At the air-biofilm interface, the distribution of toluene concentration follows Henry's law. The gas-phase equation and biofilm phase equation were established, and the biodegradation of toluene in the unit time of the biofilm as a unit at a certain height of the packing layer was derived the amount:

$$
\int_{0}^{\delta_{b}} k \cdot a \cdot \alpha \cdot C_{b} d_{x}=2 k a \alpha \sqrt{\frac{\delta_{b}}{M}}\left(K_{1}-K_{2}\right) \cdot C_{s}
$$

In the formula: $\mathrm{a}$ is the specific surface area of the filler, $\alpha$ is the effective coefficient of the biofilm;

At this time, according to the principle of mass balance, the reduction amount of toluene in the reactor should be equal to the degradation amount in the biofilm, in steady-state there are:

$$
-Q \cdot d C_{g}=\left(2 k a \alpha \sqrt{\frac{\delta_{b}}{M}}\left(K_{1}-K_{2}\right) \cdot C_{s}\right) \cdot d_{z}
$$

In the formula: Q- gas flow, $\mathrm{m}^{3} / \mathrm{h}$;

$\mathrm{C}_{\text {gin }}$-concentration of toluene in the gas phase at the reactor inlet, $\mathrm{g} / \mathrm{m}^{3}$

When the boundary condition is $\mathrm{z}=0, \mathrm{C}_{\mathrm{g}}=\mathrm{C}_{\mathrm{gin}}$

At the air membrane-biofilm interface

$$
C_{s}=C_{g} / H
$$

Putting formula (5) into formula (6), get

$$
-Q \cdot d C_{g}=\left(\frac{2 k a \alpha \sqrt{\frac{\delta_{b}}{M}}\left(K_{1}-K_{2}\right) \cdot C_{g}}{H}\right) \cdot d_{z}
$$


Points earned:

$$
\frac{C_{g}}{C_{g i n}}=\exp \left\{\left(-\frac{2 k a \alpha \sqrt{\frac{\delta_{b}}{M}}\left(K_{1}-K_{2}\right) \cdot C_{g}}{H Q}\right) \cdot z\right\}
$$

Make

$$
\mathrm{A}=\frac{2 k a \alpha \sqrt{\frac{\delta_{b}}{M}}\left(K_{1}-K_{2}\right) \cdot C_{g}}{H}
$$

Equation (8) is simplified:

$$
\frac{C_{g}}{C_{g i n}}=\exp \left(-A \cdot \frac{z}{Q}\right), C_{g}=C_{g i n} \cdot e^{\left(-\frac{A}{Q} Z\right)}
$$

It could be seen that the inlet concentration had a negative exponential relationship with the height of the filler layer. Where $\mathrm{A}$ is a constant related to the rate of biodegradation, mass transfer in the biofilm, and the specific surface area of the filler.

Figure 14 and Table 7 showed that when the inlet concentration was less than $500 \mathrm{mg} / \mathrm{m}^{3}, \mathrm{R}^{2}$ values were all above 0.99 . The regression curve could well reflect the change trend of toluene concentration with height. When the inlet concentration was greater than $500 \mathrm{mg} / \mathrm{m}^{3}, \mathrm{R}^{2}$ values does not exceed 0.91 . It may be due to the enrichment of toluene in the plexiglass columns, so it had a lagging effect on mass transfer, resulting in not ideal model fitting.

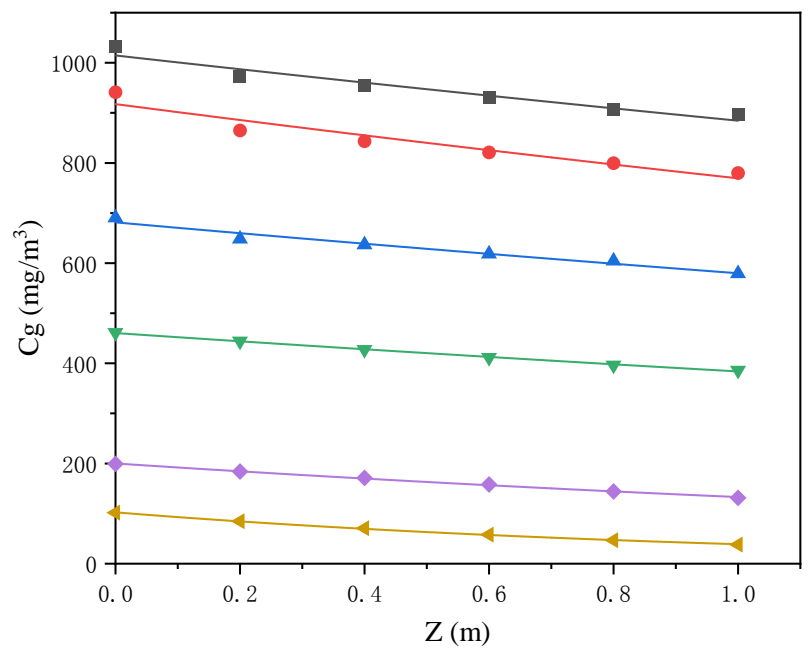

Figure 14. The fitting curve of the distribution of the concentration of toluene along with the height of filler with a different inlet concentration

Table 7. Data obtained from the fitting results

\begin{tabular}{|c|c|c|c|}
\hline Parameter & Value & Standard Error & $\mathbf{R}^{\mathbf{2}}$ \\
\hline a1 & 104.64 & 1.90 & 0.99 \\
b1 & -0.98 & 0.04 & 0.99 \\
\hline a2 & 201.01 & 1.80 & 0.02 \\
b2 & -0.40 & 2.34 & 0.99 \\
\hline a3 & 460.89 & 0.01 & \\
b3 & -0.19 &
\end{tabular}




\begin{tabular}{|c|c|c|c|}
\hline $\mathrm{a} 4$ & 680.69 & 6.58 & \multirow{2}{*}{0.91} \\
$\mathrm{~b} 4$ & -0.16 & 0.02 & \multirow{2}{*}{0.88} \\
\hline $\mathrm{a} 5$ & 912.76 & 11.02 & 0.02 \\
$\mathrm{~b} 5$ & -0.15 & 12.13 & \multirow{2}{*}{0.86} \\
\hline $\mathrm{a} 6$ & 1009.62 & 0.02 & \\
\hline $\mathrm{b} 6$ & -0.14 &
\end{tabular}

The equation is $y=a * \exp (b * x)$, $\mathrm{y}$ is $\mathrm{C}_{\mathrm{g}}, \mathrm{x}$ is $\mathrm{Z}$, a is $\mathrm{C}_{\mathrm{gin}}, \mathrm{b}$ is $-\mathrm{A} / \mathrm{Q}$, the a1-a6 in the table correspond to low concentration to high concentration in order.

Under different inlet concentrations, the values of -A/Q and A were shown in Table 8.

Table 8. The A value obtained by substituting experimental data

\begin{tabular}{|c|c|c|c|}
\hline Inlet concentration $\left(\mathbf{m g} / \mathbf{m}^{\mathbf{3}}\right)$ & $\mathbf{Q}(\mathbf{L} / \mathbf{m i n})$ & $-\mathbf{A} / \mathbf{Q}$ & $\mathbf{A}$ \\
\hline 103.92 & 30 & -0.98 & 29.4 \\
\hline 202.16 & 30 & -0.4 & 11.95 \\
\hline 459.1 & 30 & -0.19 & 5.57 \\
\hline 691.31 & 30 & -0.16 & 4.87 \\
\hline 935.22 & 30 & -0.15 & 4.57 \\
\hline 1030.35 & 30 & -0.14 & 4.28 \\
\hline
\end{tabular}

Validation of the model at lower inlet concentrations $\left(\leqq 500 \mathrm{mg} / \mathrm{m}^{3}\right)$

Taken $\mathrm{A}=12$, then

$$
C_{g}=C_{g i n} \cdot e^{\left(-\frac{12}{Q} z\right)}
$$

when $\mathrm{Q}$ was $30 \mathrm{~L} / \mathrm{min}$ and $\mathrm{Z}$ was $0.2 \mathrm{~m}$ high, the experimental data was obtained under different inlet concentration conditions were substituted into the verification model (1-13), and the results were shown in Figure 15. At a lower inlet concentration $\left(\leqq 500 \mathrm{mg} / \mathrm{m}^{3}\right)$, the correlation coefficient between the experimental data and the calculated data was 0.9995, indicating that the model was applicative.

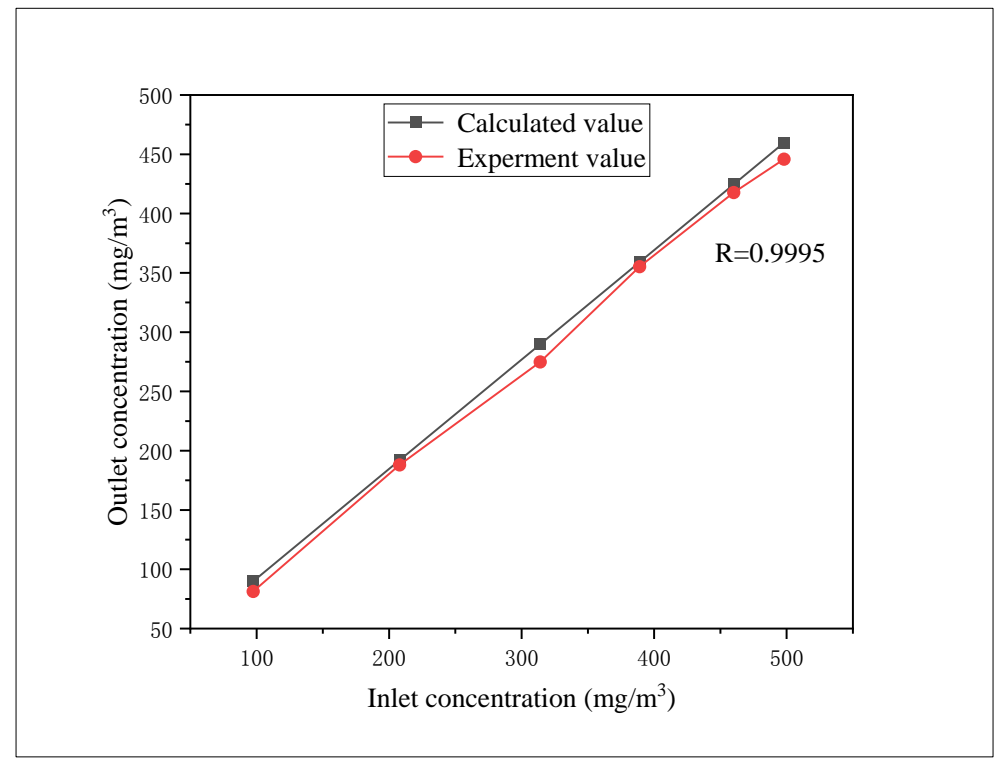

Figure 15. Comparing the result calculated by the model with experimental result for the outlet concentration of toluene 


\section{Conclusions}

The BTF offers a suitable approach to remove acrylic paint thinner exhaust gas. The best operational conditions were obtained when EC was $3.02 \pm 0.33 \mathrm{~g} \mathrm{~m}^{-3} \mathrm{~h}^{-1}$ (RE 90\%) at EBRT 300s, liquid recycling $25.46 \mathrm{~m} \mathrm{~h}^{-1}$, and inlet concentration $500 \mathrm{mg} \mathrm{m}^{-3}$. Under this circumstance, the removal efficiency of toluene and ethylbenzene was above $95 \%$, and the xylene (m-xylene, o-xylene) could reach more than $70 \%$. By gas chromatography, the organic components in the exhaust gas, bacterial liquid, and the corresponding enzymes produced by the four dominant bacteria were detected. The pathways for microorganisms to degrade pollutants were inferred. Under the action of toluene monooxygenase or toluene dioxygenase, toluene, xylene, and ethylbenzene could be converted into phenol or catechol. Moreover, phenol would further produce catechol after the adjacent hydroxylation reaction. Under the action of catechol dioxygenase, the benzene ring of catechol was fissioned to produce ketones or alcohols. Through the simulation and verification data of the two kinetic models, it was concluded that the absorption-biofilm model was suitable for the treatment of high-concentration exhaust gas, and the adsorption-biofilm model was suitable for the treatment of low-concentration exhaust gas. The results indicate that the BFT has reliable treatment efficiency in acrylic paint thinner exhaust gas abatement.

Acknowledgments: The research was supported by the Shandong Provincial Key Research and Development Program (No. 2017GSF16108); the Shandong Provincial Key Research and Development Project (No. 2018GSF117016); and the Natural Science Foundation of Shandong Province (No. ZR2017LD007).

\section{References}

1.EISELE, J., HAYNES, H., ROSAMILIA, T., Characterisation and toxicological behaviour of basic methacrylate copolymer for GRAS evaluation, Regul. Toxic. Pharm,61, 2021,32-43.

https://doi.org/10.1016/j.yrtph.2011.05.012.

2.RAHUL MATHUR, A.K., BALOMAJUMDER, C., Biological treatment and modeling aspect of BTEX abatement process in a biofilter, Bioresour. Technol, 142, 2013, 9-17.

https://doi.org/10.1016/j.biortech.2013.05.005.

3.ISMAIL, O.M., HAMEED, R.S.A., Environmental effects of volatile organic compounds on ozone layer, Adv. Appl. Sci. Res, 4 (1), 264-268.

https://www.researchgate.net/publication/309904707.

4.MOZAFFAR, A., ZHANG, Y.L., Atmospheric volatile organic compounds (VOCs) in China: a review, Current Pollution Reports, 2020. https://doi.org/10.1007/s40726-020-00149-1.

5. MALLOUL, H., MAHDANI, F. M., BENNIS, M., \& BA-M'HAMED, S., Prenatal exposure to paint thinner alters postnatal development and behavior in mice, Frontiers in Behavioral Neuroscience, 11, 2017. https://doi.org/10.3389/fnbeh.2017.00171.

6.KRISHNAMURTHY, A., ADEBAYO, B., GELlES, T., ROWNAGHI, A., \& REZAEI, F., F., Abatement of gaseous volatile organic compounds: a process perspective, Catalysis Today, 2019. https://doi.org/10.1016/j.cattod.2019.05.069.

7. LI, X., ZHANG, L., YANG, Z., Adsorption materials for volatile organic compounds (VOCs) and the key factors for VOCs adsorption process: A review. Separation and Purification Technology, 235, 2019, https://doi.org/10.1016/j.seppur.2019.116213.

8.KIM, E. H., \& CHUN, Y. N. 2016. VOC decomposition by a plasma-cavity combustor, Chemical Engineering and Processing: Process Intensification, 104, 2016, 51-57.

https://doi.org/10.1016/j.cep.2016.02.010.

9.RINNER, M., KIND, M., \& SCHLÜNDER, E.-U., Separated solvent recovery from waste gas with cryo-condensation, Separation and Purification Technology, 29(2), 2002, 95-104.

https://doi.org/10.1016/S1383-5866(02)00065-5. 
10. ZHANG, J., LI, N., NG, D., IKE, I. A., XIE, Z., \& GRAY, S., Depletion of VOC in wastewater by vacuum membrane distillation using a dual-layer membrane: mechanism of mass transfer and selectivity, Environmental Science: Water Research \& Technology, 2018.

https://doi.org/10.1039/c8ew00624e.

11.KRZYSZTOF, B., KATARZYNA, K., DAMIAN, K., KRZYSZTOF, U., VIOLETTA, K., Biological methods for odor treatment -a review, J. Clean. Prod, 152, 2017, 223-241.

https://doi.org/10.1016/j.jclepro.2017.03.093.

12. ZHOU, Q.W., ZHANG, L.L., CHEN, J.M., XU, B.C., CHU, G.W., CHEN, J.F., Performance and microbial analysis of two different inocula for the removal of chlorobenzene in biotrickling filters, Chem. Eng. J, 284, 2016, 174-181. https://doi.org/10.1016/j.cej.2015.08.130.

13. PADHI, S.K., GOKHALE, S., Benzene control from waste gas streams with a spongemedium based rotating biological contactor, International Biodeterioration \& Biodegradation. 109, 2016 96-103. https://doi.org/10.1016/j.ibiod.2016.01.007.

14.PÉREZ, M.C., ALVAREZ-HORNOS, F.J., PORTUNE, K., GABALD ON, C., Abatement of styrene waste gas emission by biofilter and biotrickling filter: comparison of packing materials and inoculation procedures, Appl. Microbiol. Biotechnol, 99, 2015, 19-32.

https://doi.org/10.1007/s00253-014-5773-9.

15.ÁLVAREZ-HORNOS, F. J., MARTÍNEZ-SORIA, V., MARZAl, P., IZQUIERDO, M., \& GABALDÓN, C., Performance and feasibility of biotrickling filtration in the control of styrene industrial air emissions, International Biodeterioration \& Biodegradation. 119, 2016, 329-335.

https://doi.org/10.1016/j.ibiod.2016.10.016.

16. MOHAMMED, S., KADIR, ALP., Removal of ethanethiol using a biotrickling filter with nitrate as an electron acceptor, Environmental Technology, 2018,

https://doi.org/10.1080/09593330.2018.1545804.

17.YOUSEFINEJAD, A., ZAMIR, S. M., \& NOSRATI, M., Fungal elimination of toluene vapor in oneand two-liquid phase biotrickling filters: Effects of inlet concentration, operating temperature, and peroxidase enzyme activity, Journal of Environmental Management, 251, 2019, 109554.

https://doi.org/10.1016/j.jenvman.2019.109554.

18.WU, C., XU, P., XIA, Y., LI, W., LI, S., \& WANG, X., Microbial compositions and metabolic interactions in one- and two-phase partitioning airlift bioreactors treating a complex VOC mixture, Journal of Industrial Microbiology \& Biotechnology, 44(9), 2017, 1313-1324.

https://doi.org/10.1007/s10295-017-1955-7.

19.OTTENGRAF, S. P. P., \& VAN DEN OEVER, A. H. C., Kinetics of organic compound removal from waste gases with a biological filter, Biotechnology and Bioengineering, 25(12), 1983, 30893102. https://doi.org/10.1002/bit.260251222.

20.LEBRERO, R., ESTRADA, J. M., MUÑOZ, R., \& QUIJANO, G., Toluene mass transfer characterization in a biotrickling filter, Biochemical Engineering Journal, 60,2011, 44-49.

https://doi.org/10.1016/j.bej.2011.09.017.

21.SUN PEISHI, HUANG BING, HUANG RUOHUA, ET AL., Kinetic model and simulation of the adsorption-biofilm theory for the process of biopurifying VOC exhaust gases, Huanjing Kexue, 23(3), 2002, 14-17. https://doi.org/10.3321/j.issn:0250-3301.2002.03.003.

22.VRIONIS, H. A., KROPINSKI, A. M., \& DAUGULIS, A. J., Enhancement of a two-phase partitioning bioreactor system by modification of the microbial catalyst: Demonstration of concept, Biotechnology and Bioengineering, 79(6), 2002, 587-594. https://doi.org/10.1002/bit.10313.

23. SUN, D.F., LI, J.J., AN, T.C., XU, M.Y., SUN, G.P., GUO, J., Bacterial community diversity and functional gene abundance of structured mixed packing and inert packing materials based biotrickling filters, Biotechnol Bioproc Eng, 17(3), 2012, 643-53.

https://doi.org/10.1007/s12257-011-0239-8. 
24. FERNANDES, M. F., SAXENA, J., \& DICK, R. P, Comparison of whole-cell fatty acid (MIDI) or phospholipid fatty acid (PLFA) extractants as biomarkers to profile soil microbial communities, Microbial Ecology, 66(1), 2013, 145-157. https://doi.org/10.1007/s00248-013-0195-2.

25. CHEN, S., ZHANG, L., Microbiology Research Techniques, Science Press, Beijing, China (in Chinese), 2006.

26. MUÑOZ, R., SOUZA, T. S., GLITTMANN, L., et al. Biological anoxic treatment of $\mathrm{O}_{2}$-free VOC emissions from the petrochemical industry: a proof of concept study, Journal of Hazardous Materials, 260(6), 2013, 442-50. https://doi.org/10.1016/j.jhazmat.2013.05.051.

27. AN T, WAN S, LI G, ET AL. Comparison of the removal of ethanethiol in twinbiotrickling filters inoculated with strain RG-1 and B350 mixed microorganisms, J. Hazard. Mater, 183(1-3), 2010, 372380. https://doi.org/10.1016/j.jhazmat.2010.07.035.

28. WU, H., YIN, Z.H., QUAN, Y., FANG, Y.Y., YIN, C.R., Removal of methyl acrylate by ceramicpacked biotrickling filter and their response to bacterial community, Bioresour. Technol, 209, 2016, 237-245. https://doi.org/10.1016/j.biortech.2016.03.009.

29. FERDOWSI, M., RAMIREZ, A.A., JONES, J.P., HEITZ, M. 2017. Elimination of mass transfer and kinetic limited organic pollutants in biofilters: a review. Int. Biodeterior. Biodegrad. 119, 336-348. https://doi.org/10.1016/j.ibiod.2016.10.015.

30. SEDIGHI, M., ZAMIR, S. M., \& VAHABZADEH, F., Cometabolic degradation of ethyl mercaptan by phenol-utilizing ralstonia eutropha in suspended growth and gas-recycling trickle-bed reactor, Journal of Environmental Management, 165, 2016, 53-61.

https://doi.org/10.1016/j.jenvman.2015.09.006.

31. MAGOC, T., SALZBERG, S.L., FLASH: fast length adjustment of short reads to improve genome assemblies, Bioinformatics, 27(21), 2011, 2957-63.

https://doi.org/10.1093/bioinformatics/btr507.

32. EDGAR, R.C., Search and clustering orders of magnitude faster than BLAST, Bioinformatics, 26 (19), 2010, 2460-1. https://doi.org/10.1093/bioinformatics/btq461.

33. FATIMA, M., SAMINA, E., NAHEED, R., Toluene degradation via a unique metabolic route in indigenous bacterial species, Archives of Microbiology, 201(10), 2019,

https://doi.org/10.1007/s00203-019-01705-0.

34. LUO, W., DU, H.-J., BONKU, E. M., HOU, Y.-L., LI, L.-L., WANG, X.-Q., \& YANG, Z.-H., An alkali-tolerant carbonyl reductase from bacillus subtilis by gene mining: Identification and application, Catalysis Letters, 2019, https://doi.org/10.1007/s10562-019-02873-w.

35.BOUHAJJA, E., MCGUIRE, M., LILES, M. R., Identification of novel toluene monooxygenase genes in a hydrocarbon-polluted sediment using sequence- and function-based screening of metagenomic libraries, Applied Microbiology \& Biotechnology, 101(2), 2017, 797.

https://doi.org/10.1007/s00253-016-7934-5.

36.WANG, LIN., SHAO, ZONG-ZE., SCREENING. Isolation and characterization of 4 benzene/ toluene-degrading bacterial strains and detection of related degradation genes, Acta Micro-biologica Sinica, 46 (5), 2006, 753-757. https://doi.org/10.1016/S0379-4172(06)60063-2.

37. ZHOU, WEI., Separation, identification and degradation characteristics of bacteria that can degrade aromatic compounds, Central South University for Nationalities, 2012.

38.VOGT, C., CYRUS, E., HERKLOTZ, I., SCHLOSSER, D., BAHR, A., HERRMANN, S., FISCHER, A., Evaluation of toluene degradation pathways by two-dimensional stable isotope fractionation, Environmental Science \& Technology, 42(21), 2008, 7793-7800.

https://doi.org/10.1021/es8003415.

39.SPAIN, J.C., NISHINO, S.F., Degradation of 1,4-dichlorobenzene by a pseudomonas sp, Appl Environ Microbiol, 53, 1987, 1010-1019. https://doi.org/10.1128/aem.53.5.1010-1019.1987.

Manuscript received: 26.06 .2021 